\title{
円柱状組物における繊維束配向の過渡的変化予測モデル
}

\author{
京都工芸繊維大学工芸科学研究科 西本博之・仲井朝美 \\ JAXA/ISAS 大谷章夫
}

\section{Prediction Method for Temporal Change in Fiber Bundle Orientation on Cylindrical Braided Preforms}

\author{
Hiroyuki Nishimoto $^{* 1}$, Akio Ohtani ${ }^{* 2}$, and Asami Nakai ${ }^{* 1}$ \\ ${ }^{* 1}$ Faculty of Textile, Kyoto Institute of Technology, Matsugasaki, Sakyo-ku, Kyoto 606-8585, Japan \\ ${ }^{* 2}$ JAXA/ISAS, 3-1-1 Yoshinodai Chuo-ku Sagamihara Kanagawa, Japan
}

\begin{abstract}
An advantage of braided composites is that the fiber bundle orientation angle, called the "braiding angle," can be changed, because the braiding angle affects the mechanical properties. Control of the angle is an important means of adjusting the stiffness distribution as required. However, when the braiding angle is changing from an initial braiding angle to a targeted braiding angle designated by the longitudinal velocity of the mandrel, some delay occurs before the actual braiding angle reaches the targeted braiding angle. The delay is caused by movement of "creating point" which is defined as a fell-down point with the braiding yarn on the mandrel. After the creating point reaches the targeted point, the braiding angle will be constant. In order to obtain the temporal change in braiding angle under unsteady-state conditions, this paper presents a step response model in braiding angle on a cylindrical braided fabric. The mechanism in the temporal change is simple. Velocity of the creating point is in proportion to distance between the current creating point and the steady-state creating point designated as the targeted angle. The solution can be described by a time constant, because the motion equation is the first-order of differential equation which is derived from geometrical position of a braiding yarn. Furthermore, the method is verified with the experimental data. As a consequence, the model has proved effective for predicting fiber orientation on a cylindrical braided preform under unsteady-state conditions.
\end{abstract}

(Received 2 December, 2010 ; Accepted 5 October, 2011)

\section{1. 緒 言}

纎維，特に連続瀻維を基材とした FRPの特徵は，強化 形態である瀻維の配向状態を製品の要求性能に合わせて 最適化できることである. Fig. 1 に丸打組物の基本的な構

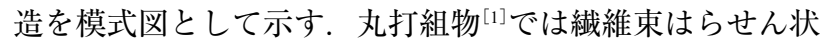
にそれぞれ左右回転しながら互いに交差して組物を形成 する。このため，作製できる組物は円筒の芯となるマン ドレルを設置した場合三次元的な中空円筒形状となる. 組物は, 纎維束が他の纎維束と交差しながら製品の長手 方向に対して斜めに配向する。この長手方向に対する繊 維束の配向角度は, 組角度 (braiding angle) と定義される. 強化形態にテキスタイルを用いた複合材料，いわゆるテ キスタイルコンポジットのプリフォーム作製技術の一つ として組物技術 (braiding technique)が優れている点は, 瀻 維束の切断部や継目のないシームレス構造を実現でき, 力学的特性に優れた構造物の作製が可能なことである.

組物技術は，機械化・自動化 ${ }^{[2-4]}$ が進められ，組物複合
材料の力学的特性を決定する組角度を自由に設定できる ことから,FRPの形状を変えずに先端部と末端部の剛性 を変えたい場合等に, 繊維束の配向状態を製品の要求性 能に合わせて最適化するテーラーメイドの手法を活用で きる特徵がある，具体的には，組角度を小さく設計すれ ば，曲げ弾性率は高くなる。こうした特徵を活かすには， 組物の繊維束配向 ${ }^{[5-7]}$ の予測が重要となる。

本研究で使用した丸打組機は，ボビンを保持したスピ ンドルが移動する機構と, 組まれた製品を引き取る機構 から構成される，スピンドルの軌道は，組物を引き取る 方向に対して垂直の平面に位置し，時計回りおよび反時 計回りの 2 経路存在する。．その 2 経路は Fig. 2 に示す外側 の円で，図では簡略化されているが，実際には互いに逆 方向に蛇行しながら交差しているため, 組糸が互いに絡 み合い, 斜め方向に配向しながら織り構造を組織し, 組 物が形成される，丸打組物は筒状の組物であるため， 、 ンドレルと呼ばれる芯棒を組物作製時に挿入することに より，マンドレルの断面形状に沿うように組物が作製さ 
れる.この状態で, 樹脂を含浸させて組物複合材料を成 形し，マンドレルを抜去することにより，マンドレルの 形状に沿った中空構造物の作製が可能となる.このとき の組角度は, 理論的には, マンドレルの断面形状, マン ドレルの移動速度, およびスピンドルの移動速度の相対 関係により決定される. スピンドルと作製される組物と の間に位置するガイドリングと呼ばれる輪は, スピンド ルから供給された数多くの組糸を, その内径側を経て収 束させ，安定的に組物を作製するために用いられる。

以上の組物作製機構および真円断面を有するマンドレ ルを幾何学的に示した模式図を Fig. 2 に示す. すべての組 糸はガイドリングを経てマンドレル上に組織されるため, 本機構を幾何学的に考慮する上で, ガイドリングを組成 円(creating circle) と定義し, 組糸がマンドレルに最初に接 触するポイントを組成点 (creating point) と定義した.

この図に示すように，マンドレルの断面形状が円形で, マンドレルの中軸と組成円の中心が一致している場合, 組角度 $\theta$ は, マンドレルの半径 $r$, 移動速度 $v$, およびス ピンドルの角速度 $\omega$ の比を用いて次式で表される.

$$
\theta=\tan ^{-1}\left(\frac{r \omega}{v}\right)
$$

しかし, Fig. 3 に示すように, 例えば組角度が $45^{\circ}$ から $30^{\circ}$ に変化するように, マンドレルの移動速度を瞬時( ス テップ状)に設定変更した場合 (Fig. 3 (a)), 実際の組角度 が設定值に達するまでには時間的な遅れが生じる．経過 時間に合わせて, 設定変更後の組角度に徐々に収束する （Fig. $3 （ b))$. このように組物作製開始時や設定変更直後 において, 組角度が設定值に達するまでの間, いわゆる 過渡状態における組角度の変化は数式化されておらず, 予測不能であった. このため, 力学的特性の要求に合わ せて, 繊維束の配向状態を最適化できるという組物の優 位性が活かされない状況にあった. そこで本研究では, この組角度の過渡的変化を予測するモデルを開発し, 実 際の組角度との比較検討を行った.

\section{2. 円柱状組物における組角度の 過渡的変化予測モデル ${ }^{[9]}$}

Fig. 4 に示すように, マンドレル移動速度を $v_{\text {in }}$ から $v_{\text {out }}$
にステップ状に変化させた場合における組角度の $\theta_{\text {in }}$ から $\theta_{\text {out }}$ への過渡的変化(組角度のステップ応答特性)について 考察する.

\section{1 モデルの前提条件}

本研究では, 過渡的変化時の組角度の予測に焦点をあ てるため, その他の条件は可能な限り単純化したモデル を考える. マンドレルの形状は円柱で, その中軸が組成 円の中心と一致する配置で, スピンドル(ボビン)から供 給される組糸に働く張力は, 組糸に弛みが生じない程度 の大きさで, 力の大きさも一定と仮定する.

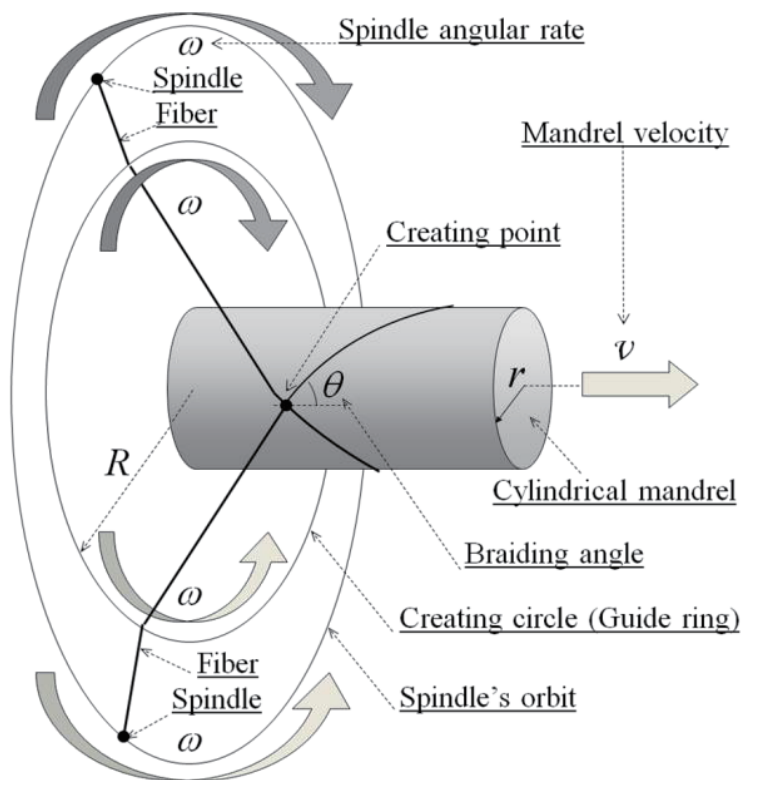

Fig. 2 Braiding mechanism in a simple model.

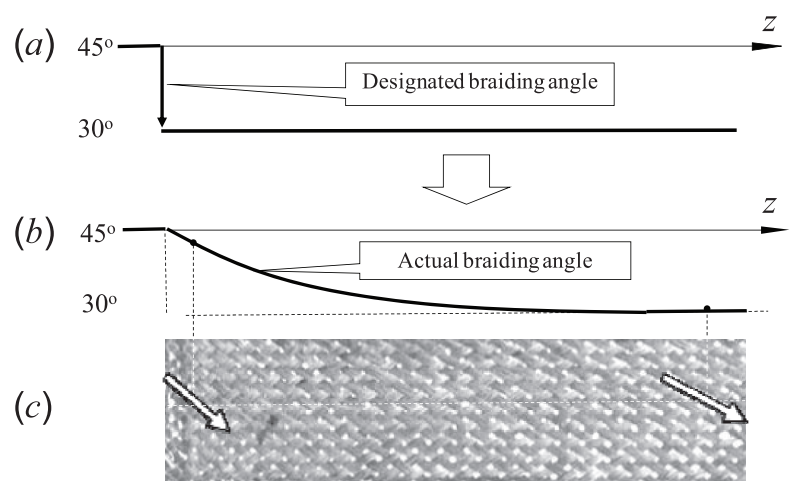

Fig. 3 Temporal change in braiding angle designated by mandrel velocity change.
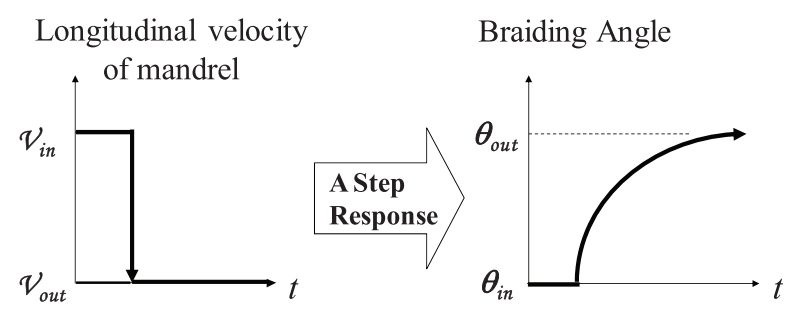

Fig. 4 Braiding angle controlled by longitudinal velocity of mandrel. 
また，本モデルでは全ての組成点が同じ方向へ一様に 移動し, Fig. 5 に示す収束領域 (conversion area) ${ }^{[6,7] に お け ~}$ る繊維束間には摩擦が無視できる程度の隙間があり, 組 糸には弾性率の高い炭素繊維を使用するため, 繊維束の 伸縮も無視できると仮定する.

逆に, マンドレルの中軸が組成円の中心から外れてい る場合には, 隣り合う繊維束間で大きな摩擦が生じ, 収 束領域の形状が組成点の挙動に大きく影響をする。この ように繊維束間の摩擦が無視できない場合, 予測值は実 際の組角度から乘離する. これが本モデルの適用限界と なる。

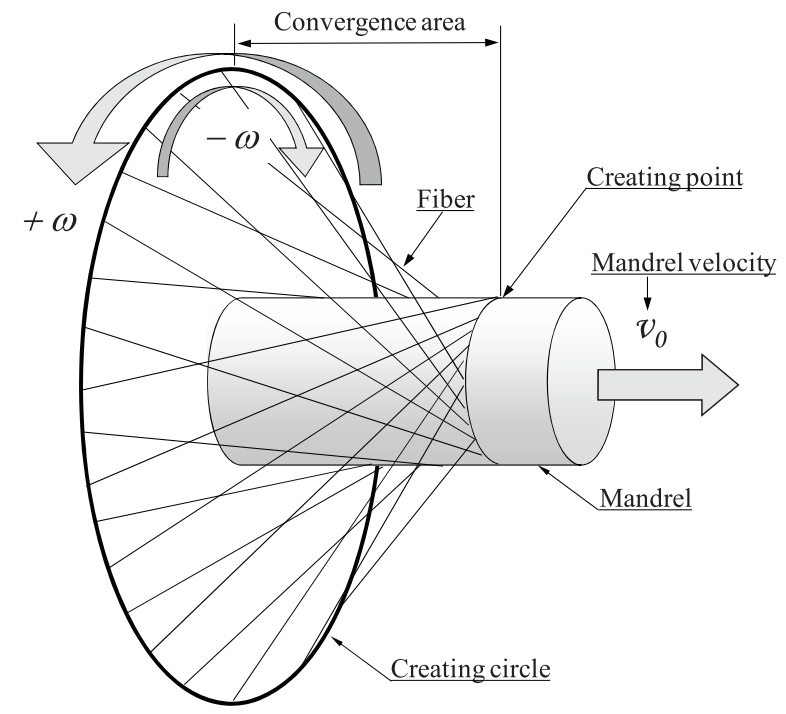

Fig. 5 Convergence area.

\section{2 組成円と組系の接点を原点とする座標系}

円柱マンドレル上では, 組角度を使って数式化するよ りも, 組成点の変位を変数に用いる方が, 予測式が単純 になることが知られている ${ }^{[6,7]}$. したがって, 本研究にお いても, Fig. 6 に示すとおり, 組成円から組成点までの距 離を $\mathrm{z}$ と定義する.すると, この距離 $\mathrm{z}$ は Fig. 2 に示した 組成円の半径 $R$, 円柱マンドレルの半径 $r$, 組角度 $\theta$ を用 いて次式で表される.

$$
z=\frac{\sqrt{R^{2}-r^{2}}}{\tan \theta}
$$

これを組角度 $\theta$ で表すと, 次式となる。

$$
\theta=\tan ^{-1}\left(\frac{\sqrt{R^{2}-r^{2}}}{z}\right)
$$

さらに, 組成点の変位を解明するには, 着目した任意 の組糸が固定される座標系が好ましいため, 組糸と組成 円との接点を原点とする座標系を設定する．実際には， スピンドルの回転に合わせて接点も移動するが, 本座標 系においては, この接点が原点となるため, 相対的にマ ンドレルが回転しながら, $\mathrm{z}$ 軸方向(組成円に対して垂直 方向)に移動していると見なされる. 円柱マンドレル上の 組角度が不変の場合, 本座標系では, 組成点は不動点と

\section{して観察される.}

本座標系を用いて，マンドレルの移動速度を $v_{\text {in }}$ から $v_{\text {out }}$ に変化させて, 組角度を $45^{\circ}$ から $60^{\circ}$ に変化させた場合の 過渡応答を示した模式図を Fig. 6 に示す.この図に示すよ うに, 実際の組角度が変化するには, 組成点も $\mathrm{A}_{\mathrm{in}}(\mathrm{z}$ 座標 : Zin) から $A_{\text {out }}(\mathrm{z}$ 座標 : Z out $)$ に移動する必要がある。この組成 点の移動に時間が必要となるため, Fig. $3(\mathrm{~b})$ に示した組角 度の変化の遅れが発生する。したがって, このステップ 応答時の組角度の過渡的変化を解明するには, 組成点の 変位に着目し, その運動方程式を導出すれば良いことが わかる。

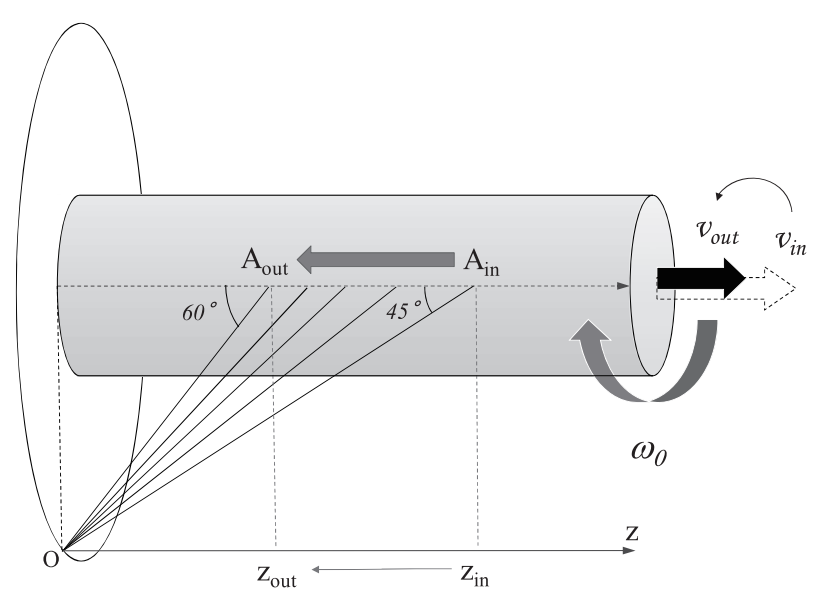

Fig. 6 Movement of a creating point under unsteadystate condition.

\section{3 組角度を形成する組成点の軌跡}

式(1)と式(3)はいずれも組角度の予測式であるが, 式 (3)には式(1) と大きく異なる点がある. 組角度は, マン ドレル上に張り付いた組糸が形成する配向角度であるが, 視点を変えると, マンドレル上に描かれる組成点の軌跡 が形成する配向角度と言い換えることが可能である。し たがって, 式(1) は, 組成点が速度 $v$ と速度 $r \omega$ の合成べ クトルの方向に移動し, その際マンドレル上に描かれる 軌跡が組角度を形成すると解釈できる. しかし, 式(1)に は過渡的变化を発生させるための速度成分が含まれてお らず，過渡状態における組角度予測式には適用できない ことがわかる.すなわち, 式(1)は, 組成点不動状態にお ける組角度の予測に適用が限定される.

これに対し, 式(3)には組成点の変位を表す変数 $\mathrm{z}$ が含 まれるため, 組成点が移動している状態での組角度予測 式として活用可能である。したがって, 本研究では式(3) を基本式として, 組角度の過渡的変化および組成点の運 動方程式を解明する.

\section{4 ステップ応答時の組成点の運動方程式}

組成点の運動方程式は, Fig. 7 に示すように, 最初にマ ンドレルの断面形状が, 半径 $r$ の円に内接する正多角形 であると想定し, その角数を無限大にすることで, 円形 の場合における組成点の運動方程式を導出する.

Fig. 8 は, Fig. 7 の角柱マンドレルの一側面のみを図式 
化したもので, マンドレルの移動速度を $v_{\text {in }}$ から $v_{\text {out }}$ にス テップ状に変化させた時の組成点の変位を示す. $\overline{P Q}$ お よび $\overline{M B_{i n}}$ は平行で, マンドレル断面の正 $\mathrm{n}$ 角形の一辺の 長さと等しい線分である.

組角度の初期值 $\theta_{\text {in }}$ と, 過渡的変化終了時の目標值 $\theta_{\text {out }}$ は, スピンドルの角速度を $w_{0}$ の一定值として, マンドレ ルの移動速度のみを $v_{\text {in }}$ から $v_{\text {out }}$ に変化させるため, 各々, 下記の式(4)と式(5)で表される.

$$
\begin{aligned}
& \angle O A_{\text {in }} P=\theta_{\text {in }}=\tan ^{-1}\left(\frac{r \omega_{0}}{v_{\text {in }}}\right) \\
& \angle O A_{\text {out }} P=\theta_{\text {out }}=\tan ^{-1}\left(\frac{r \omega_{0}}{v_{\text {out }}}\right)
\end{aligned}
$$

この角度差により, 組成点は $\mathrm{Z}_{\text {in }}$ から Z out に移動する.

ここで, スピンドルが $360 / \mathrm{n}$ 度回転する時間 (組糸が正 $\mathrm{n}$ 角形断面のマンドレルの一辺に巻きつく時間)を $\Delta t$ と定 義すると, 本座標系においては, マンドレルが回転して いると見なされるため, 原点 $\mathrm{O}$ から見た組成点 $A_{i}$ は, $\Delta t$ 後にまで変位することになる．このとき, 組成点は速度 $v_{\text {out }}$ と速度 $r \omega_{0}$ の合成べクトルの方向に移動するため, 過渡 的変化終了時の目標值 $\theta_{\text {out }}$ の方向と一致する. したがって $\angle O A_{\text {out }} P=\angle B_{i+1} A_{i} M$ である. 組成点が $B_{i+1}$ に達した とき, 組糸 $O B_{i+1}$ は, マンドレルの辺 $\overline{P M}$ に接触するた め, この接点が次の組成点 $A_{i+1}$ となり, 組角度 は $\angle B_{i+1} A_{i+1} M$ となる.

この組成点の移動は, $\Delta t$ 時間ごとに繰り返され, 最終 的に, 組角度が目標值 $\theta_{\text {out }}$ に収束するまで繰り返される. 組角度が目標值 $\theta_{\text {out }}$ に達すると, 組角度および組成点の変 化は止まる，逆に少しでも差が生じると, 組角度は目標 值 $\theta_{\text {out }}$ との差が小さくなるように変化する. したがって, この時の組成点の位置は, 組成点が安定する位置と言え る.

ここで, Fig. 8 の三角形 $O A_{i+1} A_{\text {out }}$ と三角形 $B_{i+1} A_{i+1} A_{i}$ は相似形であることより, 次式が成立する.

$$
A_{i} A_{i+1}: B_{i+1} A_{i+1}=A_{\text {out }} A_{i+1}: O A_{i+1}
$$

組成円から組成点 $A_{i}$ までの距離 $\overline{P A_{i}}=z_{i}$, 組成円から組 成点 $A_{i+1}$ までの距離 $\overline{P A_{i+1}}=z_{i+1}$ なので, 組成点の変位は 次式で表される.

$$
\overline{A_{i} A_{i+1}}=z_{i+1}-z_{i}=\Delta z
$$

また, $\Delta t$ が小さいため, $\overline{P Q}=\overline{M B_{i n}}=r \omega_{0} \Delta t$ と仮定する と次式が成立する.

$$
\overline{B_{i} A_{i}}=\frac{r \omega_{0} \Delta t}{\sin \theta_{i}}
$$

同様に, $\overline{O P}=\sqrt{R^{2}-r^{2}}$ と仮定すると次式が成立する.

$$
\begin{aligned}
& \overline{A_{\text {out }} A_{i}}=z_{i}-z_{\text {out }}=z_{i}-\frac{\sqrt{R^{2}-r^{2}}}{\tan \theta_{\text {out }}} \\
& \overline{O A_{i}}=\frac{\sqrt{R^{2}-r^{2}}}{\sin \theta_{i}}
\end{aligned}
$$

したがって，式(7)から式(10)を用いて式(6)を整理する と, 次式が成立する.

$$
\frac{\sqrt{R^{2}-r^{2}}}{r \cdot \omega_{0}} \cdot \frac{\Delta z}{\Delta t}+z_{i}=\frac{\sqrt{R^{2}-r^{2}}}{\tan \theta_{\text {out }}}
$$

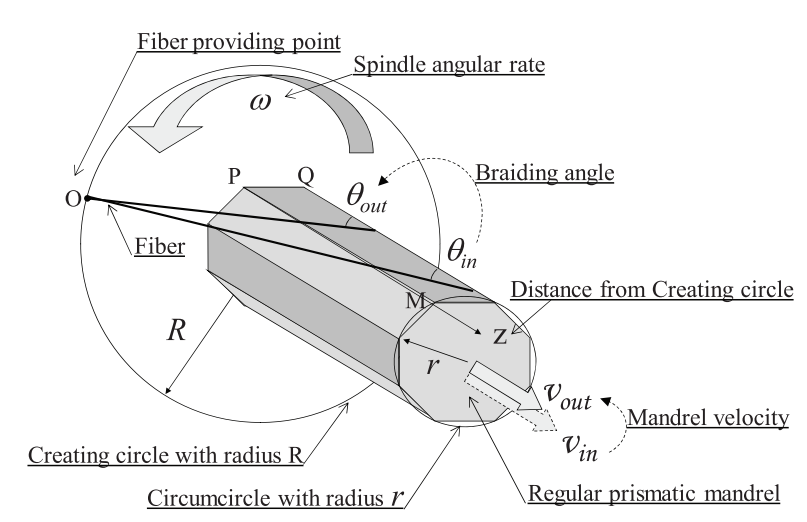

Fig. 7 Braiding angle controlled by longitudinal velocity of mandrel.

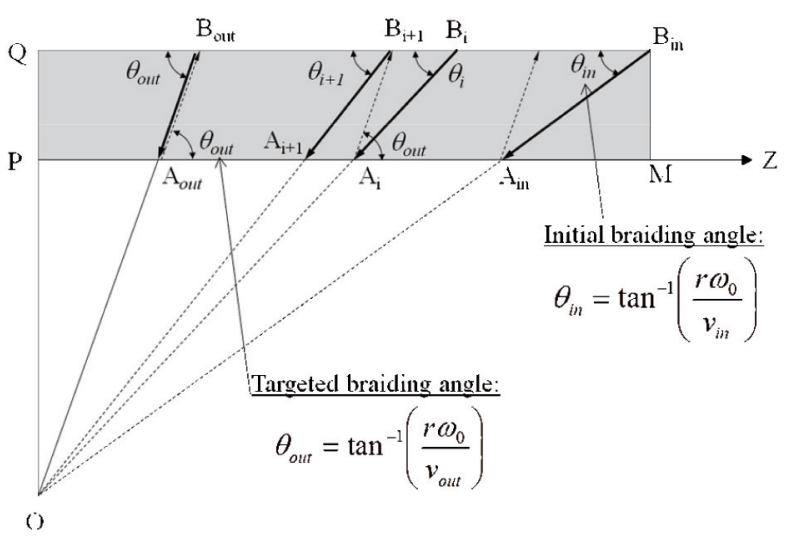

Fig. 8 Braiding angle on a lateral of regular prism.

式(15)は, 正多角柱マンドレル上の組成点の運動方程式 である.この運動方程式は, 組糸が正多角柱マンドレル に接触する瞬間から $\Delta t$ ごとの組成点の位置を表す差分方 程式である.この正多角形の角数を無限大にすることで, 円柱マンドレル上の組成点の運動方程式が導出される. したがって, 式(11)の $\Delta t \rightarrow 0$ にして, 式(11)の差分方程 式を次式のとおり微分方程式に変形する.

$$
\frac{\sqrt{R^{2}-r^{2}}}{r \cdot \omega_{0}} \cdot \frac{d z}{d t}+z=\frac{\sqrt{R^{2}-r^{2}}}{\tan \theta_{\text {out }}}
$$

式(12)の右辺は, 組角度 $\theta_{\text {out }}$ の場合の組成円から組成点ま での距離なので, 右辺を次式のとおり Z out $と$ 定義し, 


$$
z_{\text {out }}=\frac{\sqrt{R^{2}-r^{2}}}{\tan \theta_{\text {out }}}
$$

$\frac{d z}{d t}$ の比例定数を $\mathrm{T}$ とすると, 式(12) は次式となる.

$$
-T \cdot \frac{d z}{d t}=z-z_{\text {out }}
$$

ただし

$$
T=\frac{\sqrt{R^{2}-r^{2}}}{r \cdot \omega_{0}}=\frac{\sqrt{R^{2}-r^{2}}}{\tan \theta_{\text {out }}} \frac{1}{v_{\text {out }}}
$$

式(14)は, 円柱マンドレル上の組成点の運動方程式であ り, 現在の組成点と目標とする位置の距離の差に, 組成 点の移動速度が比例すること，言い換えると，式(13)が 示す組成点が安定する位置に近づくにしたがい，組成点 の移動速度は遅くなることを示す。この微分方程式の解 は自然対数を底とする指数関数となり, 比例定数 $\mathrm{T}$ は, 組成点が設定值に達するまでの応答時間の長短を示すパ ラメータとして，時定数と呼ばれる．この時定数 $\mathrm{T}$ が大 きい場合, 応答時間は長くなり, 応答特性は悪くなる。 逆に時定数 $\mathrm{T}$ が小さい場合, 応答時間は短く, 応答特性 は良くなる，これは，組成円の半径 $R$ が大きいほど，組 成点の移動距離が長くなること, 言い換えると, 組角度 が設定值に達するまでの時間が長くなることを意味する.

この微分方程式の解は次式で表される.

$$
z(t)=\left(z_{\text {out }}-z_{\text {in }}\right)\left(1-e^{-t / T}\right)+z_{i}
$$

ただし，

$$
z_{\text {in }}=\frac{\sqrt{R^{2}-r^{2}}}{\tan \theta_{i n}}
$$

ここで式(16)を式(3)に代入すると，組角度のステップ応 答時の予測式が求まる.

$$
\theta=\tan ^{-1}\left(\frac{1}{\left(\frac{1}{\tan \theta_{\text {out }}}-\frac{1}{\tan \theta_{\text {in }}}\right)\left(1-e^{-t / T}\right)+\frac{1}{\tan \theta_{\text {in }}}}\right)
$$

\section{3. 検証実験}

\section{1 実験方法}

円柱状組物の組角度のステップ応答特性を示す理論式 （18）を検証するため，丸打組機に 24 個のスピンドルを設 置し, 組糸に炭素䋐維束(東邦テナックス侏製 Tenax UT500 $-12 \mathrm{k}$ (フィラメント数 $=12000$ 本, フィラメント径 $=6.9 \mathrm{~mm}$, テックス数 $=800 \mathrm{tex})$ )を使用し, 1 纎維束当りの張力は約 10 $\mathrm{N}$ に設定し，マンドレル $(r=10 \mathrm{~mm})$ 上に組物を作製した. 組角度は, 瀻維束の配向をテープにて固定した後, 組物
をマンドレルから切り離し, 平面上に展開した状態で撮 影した画像上で測定を実施した。

ステップ応答開始時からの経過時間は, Fig. 3(c) の組物 の左端からの距離 $(\mathrm{z}$ 軸方向の距離) をマンドレルの移動速 度で除した値とした。

\section{2 実験結果}

Fig. 9 から Fig. 12 に, 組成円の半径 R が異なる場合の 実験結果を示す。縦軸は組角度, 横軸はマンドレルの移 動速度(組角度の設定值)を変化させた時刻からの経過時 間を表す. Fig. 9 および Fig. 10 は組成円の半径 $\mathrm{R}=38.0 \mathrm{~mm}$ の場合の実験結果で, Fig. 11 および Fig. 12 は組成円の半 径 $\mathrm{R}=68.0 \mathrm{~mm}$ の場合の実験結果を示す. Fig. 9 および Fig. 11 はマンドレル移動速度を加速させ, 目標とする組角度 を減少させた場合のステップ応答特性で, Fig. 10 抢よび Fig. 12 はマンドレル移動速度を減速させ, 目標とする組 角度を増加させた場合のステップ応答特性を示す．スピ ンドルの角速度は $0.176 \mathrm{rad} / \mathrm{sec}$ の一定值とし，マンドレル 移動速度を $3.20 \mathrm{~mm} / \mathrm{sec}, 1.83 \mathrm{~mm} / \mathrm{sec}, 1.07 \mathrm{~mm} / \mathrm{sec}$ と変化 させて，目標とする組角度を $30^{\circ} ， 45^{\circ} ， 60^{\circ}$ と変化させた， 式(15)に示す時定数 T は過渡的変化が収束するまでの 時間を決めるパラメータで, 時定数 $\mathrm{T}$ が, 組成円の半径 $\mathrm{R}$, マンドレルの半径 $r$, スピンドルの角速度 $\omega$ で構成さ れていることより, 式(17)から導かれる推論として, 式 （15）の時定数 T が同じ場合, 目標とする組角度に達する までの時間は, 組角度の大小に関倸なく一定值となるこ と, 組成円の半径 $R$ が小さいほど, 目標とする組角度に 達するまでの時間が短くなることが判るが, これらの点 において，実験值は式(18)と一致している.

\section{4. 結 言}

円柱状組物の組角度は, マンドレルの移動速度とスピ ンドルの角速度の比によって決定される，例えば組角度 が $30^{\circ}$ から $45^{\circ}$ になるように, マンドレルの移動速度を瞬 時に変化させても, 実際の組角度が設定值に達するまで には時間的な遅れが生じる。この遅れは, 組成点(組糸が マンドレルに接触するポイント)の移動に起因する.

この設定値を入力值とし, 実際の組成点の過渡的変化 を出力值とする特性は，ステップ応答と呼ばれる．本研 究では, この特性を解明するため, 組成点の運動方程式 を, 断面形状が正多角形の角柱マンドレルを想定し，そ の角数を無限大にすることにより導出した。これにより， ステップ応答時の組成点の移動速度が, 設定値との距離 の差に比例することを示す一階微分方程式で表されるこ とを明らかにした．この解はネイピア数を底とする指数 関数で表され，その指数部は時定数と定義される。 この モデルから導出される組角度の理論值が, 実験值とも精 度良く一致することを明らかにした，誤差が小さいこと から，本モデルで想定しなかったパラメー夕は無視でき ると考える，具体的には，予測式に組糸の張力に関する 
変数がないことから, 張力の大小が組成点の変位に影響 しないことが判る. また, Fig. 5 に示す収束領域における 繊維束間の摩擦力や炭素繊維の弾性率も無視できると考 える.これは, 組成点のまわりで力が釣り合っているこ とを意味し, 組成点は力以外の要因で移動していること が判る.

組成点のステップ応答モデルでは，この時定数 T のパ ラメータに, 組成円の半径が含まれており, この半径が 小さいほど, 組角度が設定值に達するまでの移動距離が 短くなり, 時間的な遅れが小さくなることを理論的に解 明した，言い換えると，組成円には，組角度を変更した 際に, 移動する組成点の移動量を減少させる役目も有す る. すなわち, 組成円の半径を可能な限り小さくするこ とで, 過渡的変化の影響を小さくすることができ, 設定 值との乘離の小さい組物が作製できることが示唆された.

さらに, 式(14)は, 単なる組成点の過渡的変化時の予 測式ではなく, 繊維束間の摩擦の影響を排除した特殊な 条件下における組成点の運動原理と捉えると, 他の予測 モデルの精度向上へ寄与する可能性のある理論式と考え る.

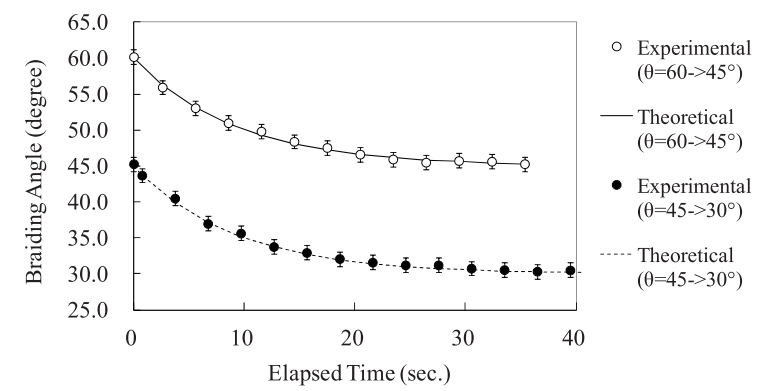

Fig. 9 A decreasing step response in braiding angle $(\mathrm{R}=38.0 \mathrm{~mm}, \mathrm{r}=10.0 \mathrm{~mm})$.

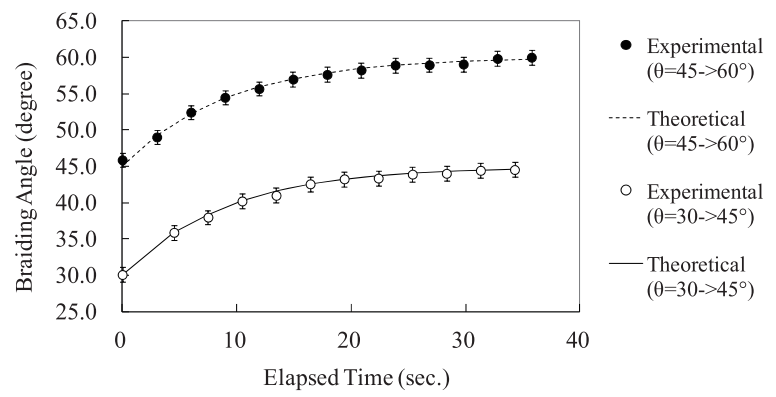

Fig. 10 An increasing step response in braiding angle $(\mathrm{R}=38.0 \mathrm{~mm}, \mathrm{r}=10.0 \mathrm{~mm})$.

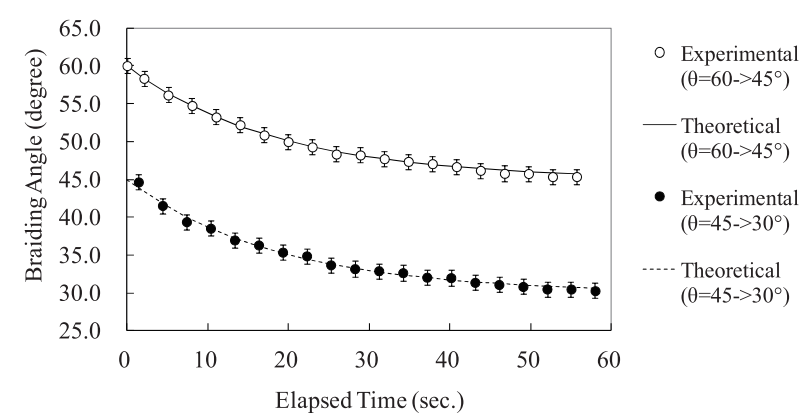

Fig. 11 A decreasing step response in braiding angle $(\mathrm{R}=68.0 \mathrm{~mm}, \mathrm{r}=10.0 \mathrm{~mm})$.

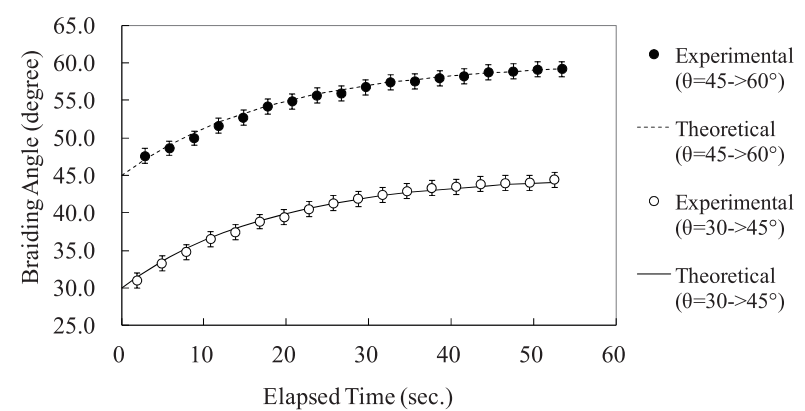

Fig. 12 An increasing step response in braiding angle ( $\mathrm{R}=68.0 \mathrm{~mm}, \mathrm{r}=10.0 \mathrm{~mm})$.

\section{文 献}

1. Tadashi Uozumi, Kumimono FRP in Japanese, Textile Mechinery Society of Japan: Vol.52, No.7, pp.290-294 (1999).

2. Makiko Tada and Hiroyuki Hamada, Determining the Structure and Manufacturing Parameters of Coupled Square Braids, Society of Fiber Science and Technology : Vol. 58, No. 2, pp.40-45 (2002).

3. Makiko Tada, Asami Nakai and Hiroyuki Hamada, Design and Method of Rotary Braiding for Coupled Square Braids with Hollow Cross Sections, Society of Fiber Science and Technology: Vol. 59, No. 6, pp.230-234 (2003).

4. Zenichiro Maekawa, Hiroyuki Hamada, Tsuneo Horino, Atsushi Yokoyama and Yasuhiko Iwasaki, Mechanical Properties of FRP with Braided Structure Part1 : Lateral Compressional Behaviors of Tubes, Textile Mechinery Society of Japan : Vol.41, No.1, pp.T1-T7 (1988).

5. Hiroyuki Hamada, Akihiro Fujita, Asami Nakai, Design Methodology for Braided Composite Tubes : 1st Report, Bending Properties, Transactions of the Japan Society of Mechanical Engineers. A : Vol.61, No.587, pp.1460-1466 (1995).

6. J.F.A. Kessels, R. Akkerman, Prediction of the yarn trajectories on complex braided preforms, Composites: Part A 33, pp.1073-1081 (2002).

7. G. W. Du, P. Popper, Analysis of circular braiding process for complex shapes. Journal of Textile Institute, 85, pp.316-337 (1994).

8. Hiroyuki Nishimoto, Akio Ohtani, Asami Nakai and Hiroyuki Hamada, Prediction Method for Temporal Change in Fiber Orientation on Cylindrical Braided Preforms, Textile Research Journal Volume 80 Issue 9, pp.814-821 (2010). 